\title{
Regional Experience of Students' Innovative and Entrepreneurial Competence Forming
}

\author{
Vasily G. Ivanov ${ }^{1}$, Albina R. Shaidullina ${ }^{2}$, Aleksander S. Drovnikov ${ }^{3}$, Sergey A. Yakovlev ${ }^{4}$ Alfiya R. \\ Masalimova $^{5}$ \\ ${ }^{1}$ Kazan National Research Technological University, Kazan, Russia \\ ${ }^{2}$ Almetyevsk State Oil Institute, Almetyevsk, Russia \\ ${ }^{3}$ Kazan National Research Technical University named after A.N. Tupolev, Kazan, Russia \\ ${ }^{4}$ Ulyanovsk State Agricultural Academy named after P. A. Stolypin, Ulyanovsk, Russia \\ ${ }^{5}$ Kazan Federal University, Kazan, Russia \\ Correspondence: Vasily G. Ivanov, Vice Rector for Academic Affairs of Kazan National Research \\ Technological University, K. Marks Street 68, Kazan, Tatarstan, 420015, Russia.
}

Received: October 24, 2014 Accepted: December 3, 2014 Online Published: December 18, 3014

doi:10.5539/res.v7n1p35 URL: http://dx.doi.org/10.5539/res.v7n1p35

\begin{abstract}
The article presents models analysis which exist in entrepreneurial activity; distinguishes the stages and peculiarities of entrepreneurial forming and development, reveals the essence of innovative entrepreneurship in conditions of education, science and manufacture integration, finds regularities and proves the principles of teachers innovative and entrepreneurial competence forming in higher technical schools, and also discloses regional practice of innovative and entrepreneurial activities implementation in the educational institutions of professional education. The material of this article is of practical value for the administration and the teaching staff of higher educational institutions of professional education in innovative and entrepreneurial activities implementation in the University, and also for teachers and students innovative and entrepreneurial competence forming.
\end{abstract}

Keywords: regional experience, innovative entrepreneurial activity, innovation and entrepreneurial competence, the teacher of the higher technical school

\section{Introduction}

The modern conditions of educational institutions of professional education are characterized by the increasing competition and modern teachers should possess not only applied professional competence, but also innovative and entrepreneurial competence, suggesting their willingness to adopt to innovations, development and marketing of their professional activities innovative products and others (Ivanov, Akhmetgareev, \& Varaksin, 2011). However, most of teachers are not focused on the innovative business activity in the scientific-educational sphere and they are not ready for its implementation (Osipov, 2006). This situation is due to the fact that the level of innovative and entrepreneurial competence development of many modern educators is not high enough.

Innovative entrepreneurship is a special creating process of something new, the process of management, based on the constant search for new opportunities, which is focused on innovation. It is concerned to entrepreneur's willingness to take on all the risk for new project implementation or existing one's improvement and as well as to be responsible for financial, moral and social factors emergency (Ivanov \& Bikbulatov, 2013).

Innovation and entrepreneurial activity in the conditions of education, science and manufacture integration is a system of measures for effective commercial activity implementation on the basis of available scientific, scientific-technical potential of the enterprise in order to create a competitive product (Shaidullina et al., 2014; Masalimova, 2013).

The whole course of entrepreneurship development and formation conditionally can be divided into four stages:

1) Stage, which is connected with sharing the entrepreneur risk (XVIII century). According to this phase, the entrepreneur is any individual possessing the vision and the desire to take risks, looking to the future, whose actions are characterized by the hope to earn income and willingness to losses. 
2) The stage of innovation determination as the main distinctive features of entrepreneurship (XIX century). The trend of the second stage of entrepreneurship's scientific understanding is characterized by innovation's allocation as its main distinctive features.

3) Stage of focusing on special personal qualities of an entrepreneur and on the role of entrepreneurship as regulatory beginning in the economic system (XX century). The distinctive feature of this stage is the focus on special personal qualities of an entrepreneur.

4) The emphasis shift phase of entrepreneurial functions on management aspect (end of XX century is characterized by the provision that in the conditions of market relations it is not enough for the entrepreneur to update the products, the technology regularly, but constantly to improve the organization of enterprise and management style (Gatiyatullin, 2008).

\section{Materials and Methods}

Models which exist in the entrepreneurial activity and their analysis (investment, inventory, institutional, intermediary, acquisition, commercial, consulting, market-games), allow to make a conclusion that the development of entrepreneurship in domestic and foreign practice represent it as developed centuries-long evolution process of values approval of a free labor, professional initiatives, practices of individual activities, which led to the entrepreneurship's approval in the economies of all developed countries of the world, including Russia, as a self-sufficient way of management (Ivanov et al., 2013). Many of these models are realized today in Russian business practice:

Table 1. Models of the entrepreneurial activity

\begin{tabular}{|c|c|c|}
\hline № & Models & Description \\
\hline 1 & Investment model & $\begin{array}{l}\text { Development and implementation of venture investment } \\
\text { projects "at one's own risk" that currently, Russia does not } \\
\text { consider to be justified. }\end{array}$ \\
\hline 2 & Inventory model & Promotion or sale of know-how (one's own or of the client). \\
\hline 3 & Institutional model & $\begin{array}{l}\text { Ideas implementation, original solutions making, availability } \\
\text { of necessary funds, communications ensuring, interactions. }\end{array}$ \\
\hline 4 & Intermediary model & $\begin{array}{l}\text { Arbitrator, mediator role performance with commissions } \\
\text { obtaining (on the basis of unique information about the needs } \\
\text { and capabilities of the parties). }\end{array}$ \\
\hline 5 & Acquisition model & $\begin{array}{l}\text { Resources accumulation and concentration for negotiating in } \\
\text { any good time. }\end{array}$ \\
\hline 6 & Commercial model & $\begin{array}{l}\text { New communications creation for goods, services, } \\
\text { information exchange. }\end{array}$ \\
\hline 7 & Consulting model & Professional support providing on a wide range of problems. \\
\hline 8 & Market-games model & $\begin{array}{l}\text { Price and other confidential information manipulation and } \\
\text { combination. }\end{array}$ \\
\hline
\end{tabular}

In scientific-pedagogical bases justification of high technical school teachers' innovative and entrepreneurial competence formation process we proceeded from the following regularities of its development:

- productivity of innovative and entrepreneurial competence formation process in conditions of education, science and manufacture integration is due to teachers openness, dynamism, readiness to innovations;

- productivity of teachers innovative and entrepreneurial competence formation process is contributed by their systematic publications, participation in conferences of different level, technical parks, innovative ideas, projects, grants, etc.;

- the integrity of innovative and entrepreneurial competence formation process is ensured in cooperation with relevant research institutes and enterprises developments, technologies and projects.

Based on identified patterns, we specify such principles of high technical school teachers' innovative and entrepreneurial competence formation as: innovation and tradition, fundamentality and orientation on practical 
activity, transparency and proportionality. The implementation of these principles focused on strategic planning and management in the innovation sphere, provision of competitive advantages of the University staff as a whole; openness and availability of the results of innovative entrepreneurial activity, as well as conservation of professional ethics.

\section{Results}

In the basis of regional practice of innovation and entrepreneurship implementation in higher technical school the following conceptual position are laid: innovation and entrepreneurial activity is carried out based on the requirements of modern manufacture and educational services, takes into account the difficulties experienced by the teacher in the process of innovative business activity implementation and the promising directions of innovation entrepreneurship business and culture development.

Student's training for innovative and entrepreneurial activities implementation appropriately should be made (simultaneously) in higher professional education unite process, via all educational disciplines contents. Higher technical education in combination with economic, legal knowledge and its practical orientation are substantive basis for students' entrepreneurial skills formation. The students receive an education in their own field and at the same time steadily acquire the system of entrepreneurial activity in the area of the profession on qualification and competence level.

Efficiency of students training for innovative and entrepreneurial activities implementation depends on creative interaction between teachers and students in the design and entrepreneurial activity, forming in students motivation for constructive management actions; on purposeful organization of students initiative creative and independent work, contributing to their leadership skills, readiness for innovation activity in the zone of reasonable risk; on entrepreneurial activity participants interaction (teachers, students, representatives of enterprises) in creating multifunctional professionally oriented, spiritual, moral, and cultural environment.

Many modern universities implementing innovative entrepreneurial business activity create on their own basis the offices of commercialization, the objectives of which are the following:

- collection and analysis of the received information, preliminary marketing research, expert assessment and recommendations providing to commercialize the most promising projects and developments;

- information search and analysis on market needs, linked with scientific activity of the University staff. Strategic order formation on scientific developments;

- case, information data base of University developments creation, suitable for commercialization and innovative developments support. Investors database, orders for scientific developments maintaining, etc;

- financing sources determination for selected projects and developments commercialization. Search of investors;

- developments presentation on competitions, grants, exhibitions, negotiations with potential buyers;

- preparation, control and maintenance of contracts on commercialization, license agreements, state contracts, contracts with managing participants, etc.;

- organization of higher education institution staff and representatives of business joint actions (seminars, conferences, round tables);

- students groups identification and organization for their perspective innovative projects implementation further support.

As to commercialization office composition, the requirements for its personnel and its job responsibilities are presented in the table. It consists of the head Master, Manager on intellectual property management and its protection, the Manager on marketing and technologies promotion, investment Manager. The composition of the office workers may be adjusted depending on the work amounts (the number and quality of projects that are in process). 
Table 2. Almetyevsk State Oil Institute developments commercialization office staff

\begin{tabular}{|c|c|c|}
\hline Duty & Duty activities & Demands to the candidate \\
\hline Head Master & $\begin{array}{l}\text { - Work Planning on all major activities directions at the } \\
\text { office } \\
\text { - Interaction with University academic departments } \\
\text { heads } \\
-\quad \text { Work organization on university scientific } \\
\text { developments information collection } \\
-\quad \text { Interaction with University administration and state } \\
\text { structures } \\
-\quad \text { Negotiations with intellectual property potential } \\
\text { buyers. } \\
-\quad \text { Personnel management office }\end{array}$ & $\begin{array}{l}\text { - Experience of work in high school } \\
\text { - Experience of leadership in } \\
\text { innovative business } \\
\text { - Analytical skills } \\
\text { - Knowledge of management basics, } \\
\text { including the staff management. } \\
\text { - Negotiation skills, communication } \\
\text { skills, knowledge of foreign languages }\end{array}$ \\
\hline $\begin{array}{l}\text { Manager on } \\
\text { intellectual } \\
\text { property } \\
\text { management } \\
\text { and its } \\
\text { protection }\end{array}$ & $\begin{array}{l}\text { - Initial assessment of intellectual properties } \\
\text { commercial properties resulting from research activities } \\
\text { of the University } \\
\text { - Protection of University intellectual property } \\
\text { - Legal documents making linked to the relations of the } \\
\text { University with partners relating to intellectual property } \\
\text { - Database maintenance on developments offered for } \\
\text { sale }\end{array}$ & $\begin{array}{l}\text { - Professional level of Russian } \\
\text { Federation patent attorney } \\
\text { - Knowledge of marketing } \\
\text { - Knowledge of normative documents } \\
\text { related to intellectual property } \\
\text { - Ability to maintain databases }\end{array}$ \\
\hline $\begin{array}{l}\text { Manager on } \\
\text { marketing and } \\
\text { technologies } \\
\text { promotion }\end{array}$ & $\begin{array}{l}\text { - Marketing of intellectual property within the region } \\
\text { and beyond it } \\
\text { - Market research in the technological sectors, which } \\
\text { are appropriate to the University scientific research theme } \\
\text { - Joint scientists and business representatives activities }\end{array}$ & $\begin{array}{l}\text { - All marketing methods possession, } \\
\text { including marketing of new products } \\
\text { - Abilities to organize } \\
\text { - Knowledge of foreign languages }\end{array}$ \\
\hline $\begin{array}{l}\text { Investment } \\
\text { manager }\end{array}$ & $\begin{array}{l}\text { - } \quad \text { Business planning } \\
\text { - } \quad \text { Funding search for projects commercialization } \\
\text { - } \quad \text { Investors search for newly established companies on } \\
\text { the basis of University developments } \\
\text { Innovative projects management }\end{array}$ & $\begin{array}{l}\text { - Knowledge in the field of business } \\
\text { planning and financial management } \\
\text { - Knowledge of investment schemes, } \\
\text { their optimization, financing sources } \\
\text { - Tax legislation knowledge }\end{array}$ \\
\hline
\end{tabular}

Such units allow to systematize the work on innovative products promotion, to receive additional income as for higher education institution so for individual scientists, to create an environment for competitive specialists training, who is capable to perceive adequately, to generate and implement innovations, receive competence in the field of research and development, motivation to innovate.

\section{Discussions}

The basic ideas of philosophy, history and theory of entrepreneurship are stated in the works of Berdyaev (1994), Bulgakov (1993), Voloshin (1995), Zarubina (1995), Kagan (1997), Strumilin (1960), Tagirov (1994) and others. Fundamentals and technologies of small business have been studied and described in publications of Germogenova (1994), Grachev (1997), Dyachkova (1998), Kostyaev (2002), Nefedova (1997) and others. Theory and practice of effective management, management for entrepreneurs are considered in the works of Bovykin (1997), Bolt (1991), Woodcock (1991) and others. The psychological portrait of specialist personality, Manager, entrepreneur, head master is described in the works of Averchenko (1993), Kibanov (2001), Faiole, Ford, and Tailor (1992) and others. The issues of small business development and formation of students entrepreneurial competences formation are considered in dissertation researches in the field of economic Sciences by K. R. Abdoulgamidov, V. Lyubkina, M. L. Nyushenkova, etc.

Despite a rather stable interest of a wide circle of scientists to entrepreneurship as a scientific problem, it is not 
reflected in scientific and pedagogical works. In the above studies pedagogical component of the business, as a rule, is absent, and socio-cultural component is negligible. In modern socio-economic conditions, educational, moral and ethical orientation of entrepreneurial activity can change significantly its quality and effectiveness. It actualizes the need for special studies aimed at understanding the pedagogical problems of innovation and entrepreneurial activity of higher educational institutions.

\section{Conclusion}

Thus, the advantage of commercialization office is that it promotes to collaboration of the institutes departments in the process of scientists developments transferring to the final products and bringing them to the market; the University receives revenue from intellectual activity results sale; the process of education is innovative in nature, promotes to innovative person and innovative personality formation (such tasks are given for universities in "the Strategy of innovative development of Russia till 2020").

Modern universities today have to conduct not only fundamental, search and applied scientific researches, but also to create new equipment and technologies, to ensure their distribution, research results commercialization, ready products transferring (technology transfer) to the consumer. Thus modern universities are transformed into scientifically innovative educational University complexes.

\section{References}

Abdulgamidov, K. R. (1997). Entrepreneurship as a social phenomenon (socio-economic analysis) (p. 151). Thesis $\mathrm{PhD}$, Moscow.

Averchenko, L. K. (1993). Self-identity manager. Eco, 8, 196-197.

Berdyaev, N. A. (1994). The philosophy of the free spirit (p. 479). Moscow: The Republic Press.

Bolt, G. (1991). A practical guide to sales management (p. 271). Moscow: Economy Press.

Bovykin, V. I. (1997). New management (business management at the highest standards, the theory and practice of effective control) (p. 368). Moscow: Publishing house of "Economy".

Bulgakov, S. N. (1993). Works in 2 volumes. Volume 1: Philosophy of Economy. Tragedy philosophy (p. 269). Moscow: Nauka press.

Dyachkova, E. K. (1998). Imagelogy for the manager (p. 84). Novosibirsk.

Fayolle, A., Emerson, G., Taylor, F., \& Ford, G. (1992). Management - the science and art (p. 124). Moscow: Republic Press.

Gatiyatullin, M. H. (2008). Modeling and design process of preparation of students of a technical college for entrepreneurship (p. 376). Moscow: Publishing House of "Drofa".

Germogenova, L. Y. (1994). Effective advertising in Russia. Recommendations (p. 252). Moscow: Russian Partner Press.

Grachev, Y. N. (1997). Negotiating with foreign companies (p. 128). Moscow: JSC Business School "Intel-Synthesis" Press.

Ivanov, V. G., Akhmetgareev, R. A., \& Varaksin, V. E. (2011). Competence model of formation of readiness for future professionals to innovative professional activities in the "high school - the troops". Herald Kazan State Technological University, 4, 242-244.

Ivanov, V. G., \& Bikbulatov, R. R. (2013). The development of gifted students personality in the process of their training for getting engineering education. Herald Kazan State Technological University, 16, 142-145.

Ivanov, V. G., Gerasimov, S., Svetlakov, A. P., \& Shaposhnikov, S. O. (2013). Formation of system engineering training for new industrialization. Bulletin of Kazan State Technological University, 16, 103-109.

Kagan, M. S. (1997). Philosophical theory of values. Petro policy Press (p. 205). St. Petersburg.

Kibanov, A.Y. (2001). Personnel management: Regulation of labor (p. 640). Exam Press. Moscow.

Kostyaev, P. A. (2002). Online business: Finance, marketing, planning (p. 656). St. Petersburg: BHV-Petersburg Press.

Lyubkina, V. (1994). Teaching and working conditions of preparing students to work in small business (p. 184) (Thesis PhD, Moscow).

Masalimova, A. R. (2013). Corporate training the mentors (p. 183). Kazan: Printing Service - XXI Century Press. 
Nefedova, V. I., \& Vlasova, S. Y. (1997). I and my image (p. 204). Moscow, Jauza: EC-SMO-Press.

Nyushenkova, M. L. (1994). Entrepreneurial activities of the organization culture (p. 160). Samara: SGAKI Press.

Nyushenkova, M. L. (1995). Image, goodwill, public relations services as a condition for promotion of cultural organizations (p. 56). Samara: SGAKI Press.

Osipov, P. N. (2006). Vocational education and labor market: Cooperation. Kazan Pedagogical Journal, 2, 10-13.

Rudenskiy, E. V. (1997). Fundamentals of psychology, communication manager (p. 215). Moscow-Novosibirsk: FRA-M Press.

Shaidullina, A. R., Masalimova, A. R., Vlasova, V. K., Lisitzina, T. B., Korzhanova, A. A., \& Tzekhanovich, O. M. (2014). Education, science and manufacture integration models features in continuous professional education system. Life Science Journal, 11(8), 478-485.

Strumilin, S. G. (1960). Essays on the economic history of Russia (p. 132). Moscow.

Tahirov, E. Mal'gin B., \& Spirgachev G. (1994). Entrepreneurship: History, development strategy (p. 128). Kazan: zd KFEI Press.

Voloshin, V. N. (1995). Philosophy and Sociology of Human Sciences (p. 388). St. Petersburg: Asta-Press.

Woodcock, M., \& Francis, D. (1991). Liberated Manager: For head-practice (p. 319). Moscow: Case Press.

Zarubina, N. (1995). Russian Entrepreneurship. Ideas and People. Problems of Economics, 7, 148.

\section{Copyrights}

Copyright for this article is retained by the author(s), with first publication rights granted to the journal. This is an open-access article distributed under the terms and conditions of the Creative Commons Attribution license (http://creativecommons.org/licenses/by/3.0/). 